\title{
Participation by Women in the 1999 APSA Annual Meeting
}

\author{
Martin Gruberg, University of Wisconsin, Oshkosh
}

This is the twenty-eighth year I have been monitoring participation by women at our Annual Meeting. It is also the thirtieth anniversary of the Women's Caucus for Political Science. These PS reports have documented the ascent of women in our profession. While there are signs that women have continued to move ahead in their participation, the picture is mixed.. The best year for female chairpersons was 1994 .

Since then, there has been some slippage. The most successful year regarding the ratio of female-to-male papergivers was 1996, though 1998 and 1999 had the most women papergivers to date. Nineteen ninety-three saw the apex for female discussants, though 1998 had the most female discussants.

\begin{tabular}{|c|c|c|c|}
\hline \multicolumn{4}{|c|}{ Chairpersons } \\
\hline Year & Total & Women & Percentage \\
\hline 1971 & 154 & 12 & 7.8 \\
\hline 1981 & 137 & 16 & 11.7 \\
\hline 1991 & 439 & 107 & 24.4 \\
\hline 1992 & 463 & 106 & 22.9 \\
\hline 1993 & 452 & 115 & 25.4 \\
\hline 1994 & 509 & 164 & 32.2 \\
\hline 1995 & 480 & 134 & 27.9 \\
\hline 1996 & 517 & 136 & 26.3 \\
\hline 1997 & 503 & 143 & 28.4 \\
\hline 1998 & 521 & 115 & 22.1 \\
\hline 1999 & 637 & 161 & 25.3 \\
\hline \multicolumn{4}{|c|}{ Papergivers } \\
\hline Year & Total & Women & Percentage \\
\hline 1971 & 552 & 43 & 7.8 \\
\hline 1981 & 520 & 98 & 18.8 \\
\hline 1991 & 1940 & 512 & 26.4 \\
\hline 1992 & 1986 & 445 & 22.5 \\
\hline 1993 & 2053 & 525 & 25.6 \\
\hline 1994 & 2200 & 576 & 26.2 \\
\hline 1995 & 2160 & 598 & 27.7 \\
\hline 1996 & 2414 & 781 & 32.4 \\
\hline 1997 & 2419 & 669 & 27.7 \\
\hline 1998 & 2825 & 811 & 28.7 \\
\hline 1999 & 2809 & 789 & 28.1 \\
\hline \multicolumn{4}{|c|}{$\underline{\text { Discussants }}$} \\
\hline Year & Total & Women & Percentage \\
\hline 1971 & 184 & 13 & 7.1 \\
\hline 1981 & 161 & 28 & 17.4 \\
\hline 1991 & 455 & 120 & 26.4 \\
\hline 1992 & 568 & 118 & 20.8 \\
\hline 1993 & 521 & 152 & 29.2 \\
\hline 1994 & 594 & 157 & 26.4 \\
\hline 1995 & 583 & 157 & 26.9 \\
\hline 1996 & 574 & 142 & 24.7 \\
\hline 1997 & 575 & 161 & 28.0 \\
\hline 1998 & 708 & 183 & 25.8 \\
\hline 1999 & 630 & 171 & 27.1 \\
\hline
\end{tabular}

As Ive noted previously, where women head divisions or panels, there is a greater likelihood of other women being selected for program contributions. This year, a female co-chaired the Program Committee. In 1999 , 21 of the 49 division chairs were women (42.9\%) (cf., 1995: 38.8\%; 1996: 30.06\%; 1997: $37.3 \% ; 1998: 36.2 \%$ ). The divisions they headed had women as $29.1 \%$ ( 88 of 302 ) of the panel chairs, $29.6 \%$ (406 of 1370) of the papergivers, and $28.4 \%$ (92 of 324 ) of the discussants (cf., 1995: 30.7\%, 34.2\%, 31.0\%; 1996: $26.1 \%, 35.1 \%, 29.8 \% ; 1997: 35.4 \%$, $32.1 \% 31.4 \% ; 1998: 31.8 \%, 38.8 \%, 36.7 \%)$.

The divisions led by women had $54.7 \%$ of the convention's female panel chairs, $51.5 \%$ of the papergivers, and $53.8 \%$ of its discussants (cf. 1995: 44.0\%, 48.0\%, 42.0\%; 1996: $40.4 \%, 48.1 \%, 50.7 \% ; 1997: 60.1 \%, 54.0 \%$, $53.4 \% ; 1998: 59.1 \%, 51.0 \%, 49.7 \%)$. Womenchaired panels had $38.7 \%$ female paper givers and $45.3 \%$ female discussants (cf., 1995: $41.0 \%, 42.5 \% ; 1996: 38.7 \%$. 33.9\%; 1997: $37.7 \%, 43.0 \% ; 1999: 41.1 \%, 49.4 \%$ ). These constituted $35.6 \%$ of the women giving papers at the 1999 meeting and $45.6 \%$ of the women serving as discussants (cf., 1995: 48\%, $43.3 \% ; 1996: 30.9 \%, 30.3 \% ; 1997: 38.0 \%$, $40.4 \% ; 1999: 33.8 \%, 43.7 \%)$.

The divisions with the strongest female representation were those on Foundations of Political Theory, ${ }^{*}$ Normative Political Theory, Political Psychology, Comparative Politics," State Politics and Policy, ${ }^{*}$ Urban Politics; Women and Politics, * Race, Ethnicity and Politics, ${ }^{*}$ and Political Communication.

The divisions with the weakest female representation in 1999 were those on Political Science and the World of Politics and Policy, * Formal Political Theory, Politics and Society in Western Europe, International Collaboration, International Security and Arms Control, Domestic Sources of Foreign Policy/ Foreign Policy Analysis, Conflict Processes, ${ }^{*}$ Constitutional Law and Jurisprudence, Religion and Politics, Representation and Electoral Systems, * Elections and Voting Behavior,* Computers and Multimedia, and Ecological and Transformational Politics."

Among the predominantly female panels (omitting the panels in Women and Politics) were those on Commodities and Enchantment; Sexual Violence and Political Legitimation; Gender Politics: Punishment, Tolerance, Care, Voice; Feminist Ethics and Political Theory; The Political Psychology of Scandals;
Citizenship and the Political Construction of American Identity; Feminist Methodology in Political Science; Public Policy and Women's Choices; Crossing Borders: Women as Migrants and Refugees; Courts, Citizens, Interest Groups, and Direct Democracy in the States; and Feminist Voices.

Panels lopsidedly "stag" included Enlightenment Political Science; Political Theory in Practice in the Real World; Thucydides and the Obstacles to Realism; Civilization, Statesmanship and the Scottish Enlightenment; Juries and Polls; Emerging Political Institutions; Roundtable on "Mr. President, If You Had Read My Book... ."; Social Scientists in the Public World; Citizenship and the Political Construction of American Identity; Distance Learning Ventures; What Have We Learned about Democratic Consolidation?; Business Associations and the State in the Developing World; Thucydides on International Security after the Cold War; The Political Economy of Standards Setting in Integrated Markets; Innovation, Organizations, Beliefs and the OffensiveDefensive Balance; India, Nuclear Weapons, and World Order; Is Anyone Still a Realist?; Explaining Conflict; Recent Research on Power Transition Theory; Formal Models of Alliance Design; Quantitative Analysis of the Impact of Race, Gender, and Culture on Interstate War; Murder in the Middle of Pacification?; Saving the World One Coefficient at a Time; Political Careers at the Subnational Level from a Comparative Perspective; Presidential Elections; Georgia's HOPE Scholarship; Roundtable on Fifteen Years of Congressional Dominance; Federal Appellate Courts; Constitutional Interpretation; Elephants in Dixie; The Many Sides of Political Influence; Religion and Politics in Liberal Democracies; Religion, Pluralism, and the Social and Political Order; The Comparative Politics of Electoral Administration; Electoral Systems and Strategic Voting; Political Parties in Transition; Presidential Election Politics; The Effect of Competition on Vote Choice and Turnout; When and How to Go Negative; Economic Conditions and Electoral Choice; Political Parties and Democratic Choice; Issues in the Measurement of Attitudes and Behavior; Media as Dependent and Independent Variables in Political/ Policy Processes; and Political Information Sources and Processing.

* Chaired by women. 